\title{
Designing Marine Current Micro-Hydro Power Plants
}

\author{
Andrea Stevens Karnyoto ${ }^{1}$, Parea Rusan Rangan ${ }^{2}$, Yusri Anugerah Manapa Ambabunga ${ }^{3}$, \\ Abedneigo Carter Rambulangi ${ }^{4}$, Martina Pineng ${ }^{5}$ \\ 1(Teknik Informatika, Fakultas Teknik Universitas Kristen Indonesia Toraja) \\ 2 (Teknik Sipil, Fakultas Teknik Universitas Kristen Indonesia Toraja, TanaToraja) \\ 3 (Teknik Elektro, Fakultas Teknik Universitas Kristen Indonesia Toraja) \\ 4 (Manajemen, Fakultas Ekonomi Universitas Kristen Indonesia Toraja) \\ 5 (Teknik Elektro, FakultasTeknik Universitas Kristen Indonesia Toraja)
}

\section{Abstract:}

Indonesia is an archipelago country. Today, Indonesian government continues to increase support to entrepreneurs engaged in renewable-energy. Based on the observation of the researchers, BarrangLompo is one of the islands in the province of South Sulawesi that inhabited by about 4000 people still using diesel power plants. Costly diesel oil and oil transportation constraints cause the diesel power plant to be used only at $6 \mathrm{pm}$ to $12 \mathrm{pm}$. Develop a Marine Current Micro-Hydro Power Plants can be a solution for people in the small island because it is too difficult to connecting electricity from power source in the main island. We hoped with these design people can be easy to build their marine current power plant.

Keywords - Develop power plants, Marine Current, Micro-hydro, Power Plant for archipelago country, Renewable-energy.

\section{INTRODUCTION}

Indonesia is an archipelago country. In 2002, National Institute of Aeronautics and Space (LAPAN) confirms there are 18,306 total number islands of Indonesia. In 2013, the Ministry of Maritime and Fisheries Affairs (KKP) recorded that 87.62 percent or 15,337 islands in Indonesia are uninhabited. It indicates that there is 12.38 percent or 2,969 islands are inhabited. In fact, Data of Ministry of Home Affairs based regents/mayors reports from governors and regents/mayors, in are stated that 7,870 islands are named, while 9,634 islands are not named. Indonesia's land area is $1,922,570 \mathrm{~km}^{2}$, and its sea area $3,257,483 \mathrm{~km}^{2}$, the percentage of sea area is $62.88 \%$ of the total area of Indonesia.

Based on the observation of the researchers, BarrangLompo is one of the islands in the province of South Sulawesi that inhabited by about 4000 people still using diesel power plants. Costly diesel oil and oil transportation constraints cause the diesel power plant to be used only at $6 \mathrm{pm}$ to $12 \mathrm{pm}$. With these conditions resulted in residents barely able to apply electrical equipment to support their lives outside these hours. On the other hand, the potential of sea waves is possible to be utilized as an alternative energy source. Densely populated island like BarrangLompo still lacks electric power. We can conclude the electricity condition of islands which with small population surely the very concern.

Currently, the Indonesian government continues to increase support to entrepreneurs engaged in renewable-energy. In 2017, the Ministry of Energy and Mineral Resources (ESDM) provides an opportunity to work up incentives for renewableenergy developers. $87 \%$ of the nationally generated electricity is enjoyed by urban communities, while 2500 villages in Indonesia still pitch blank. According to the Electricity Supply Business Plan (RUPTL), Indonesian governments expected the utilization of clean energy would contribute 22.4 percent to the total national energy in 2026. This number is far off if compared to development of renewable-energy until the end of 2016, which is only 11.9 percent in the total generated energy. Business opportunity in the renewable-energy field to meet the target in the next eight years is auspicious. In line with the government's program 
on renewable energy and geographical potential of Indonesia, the researcher designs a power plant that can be appropriate in the archipelago.

Globally, Up to 70 percent of earth's surface is covered up with oceans, which constitutes the ample amount of energy of the form of wave, tidal, marine current and thermal gradient [1]. The total wave's energy in the world coasts is estimated to be $10 \mathrm{MW}$ and if only $2 \%$ of this energy is extracted it can supply the total world energy demand [3]. This largely untouched resource could play a vital role not only in compensating for depleting energy sources but provide a solution to the ever-increasing demand for electricity [1]. Generally, ocean waves are categorized into wind-sea and swell waves. The wind-sea is used for the waves that generated by the local winds, and waves move in the direction of these winds. The waves with long period generated in the stormy regions are called swell waves. The swell waves with very low energy losses spread from coast to coast [2]. Wave power refers to the energy of ocean surface waves and the capture of that energy to do useful work. Sea waves are a very promising energy carrier among renewable power sources, since they are able to manifest an enormous amount of energy able to manifest an enormous amount of energy Resources in almost all geographical regions. The global theoretical energy from waves corresponds to $8 \times 106 \mathrm{TWh}$ per annum, which are about 100 times the total hydroelectricity generation of the whole planet [4]. Once you have built it, the energy is free because it comes from the ocean's wave power. It is important to estimate what amount of power generation will make a company profitable [4].

The current marine power plant can contribute to the supply of electricity to the archipelago. Potentials of ocean currents are never exhausted to drive turbines all the time. According to observations by researchers, in the sea area of the Flores island occur two times the rise of seawater in a day, it indicates that the section has an active ocean current. Furthermore, currently the development of generator technology is also very advanced. The LOW RPM generator can provide excellent electrical output results despite low turbine spin [5]. Using the aluminium as a power plant materials has several advantages that are stainless, lightweight and easy to obtain. With this power plant design expected that islands are far apart from the mainland get electricity at all times.

\section{THE DESIGN}

\section{A. Buoys}

To float the power plant and follow the sea level using the buoys.

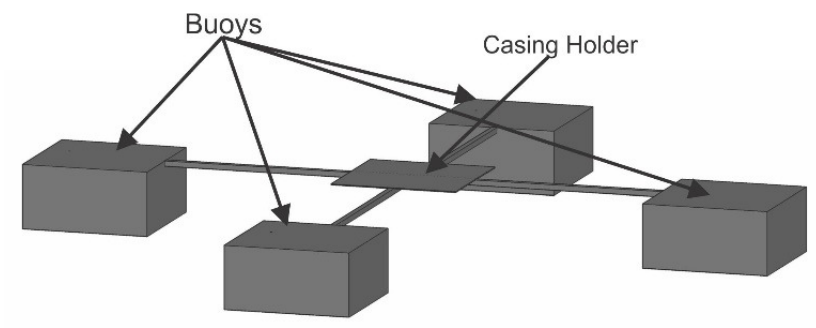

Fig 1. The buoys

Figure 1 shows the buoy. The material of buoys made using the aluminium, for frames made using aluminium hollow and for walls using aluminium plates. Frames are required, so the buoys to become firm against the impact of other floating objects. For a power plant, it takes four buoys to provide balance, aluminium rods connecting the buoys. In the corners of the buoys will also be given a binder of anchor or binder to connecting from one power plant to another plant by using rope.

\section{B. Fin}

The turbine fin is used to capture ocean currents, if the ocean currents flow from back to the front of the fins, the fins will be opened, and if the ocean currents flow from the front to back of the fins, the fins will be closed. 


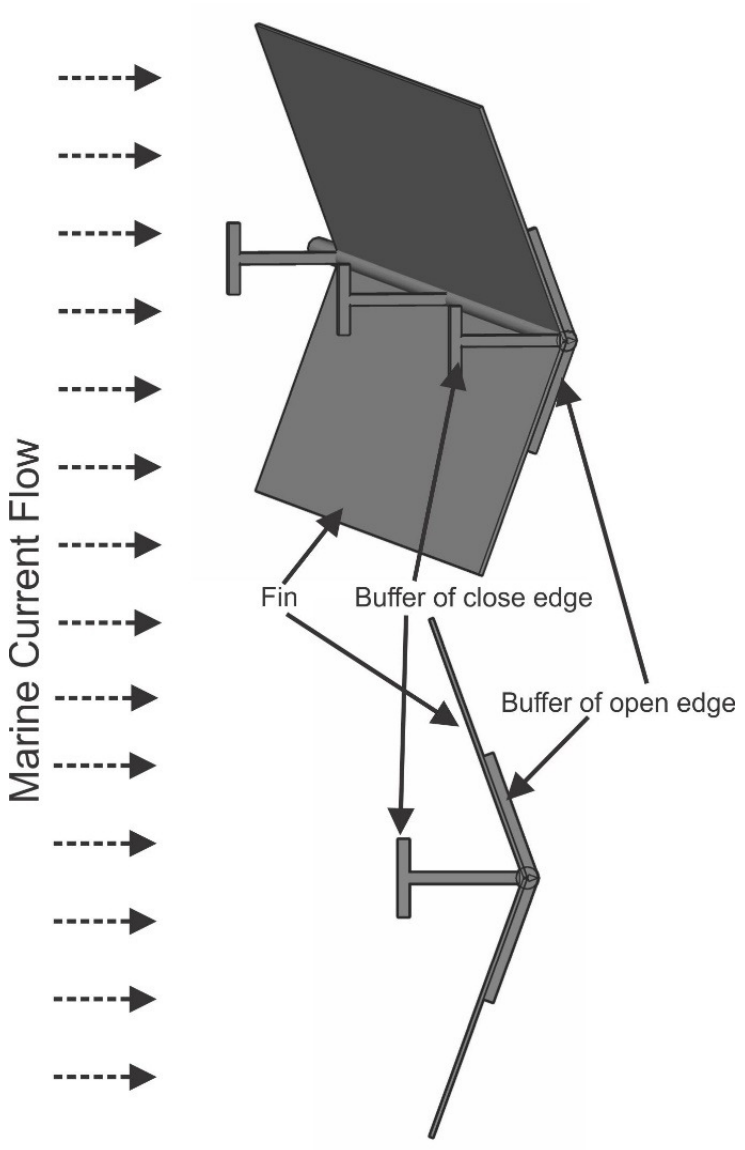

Fig 2. Opened fin Position

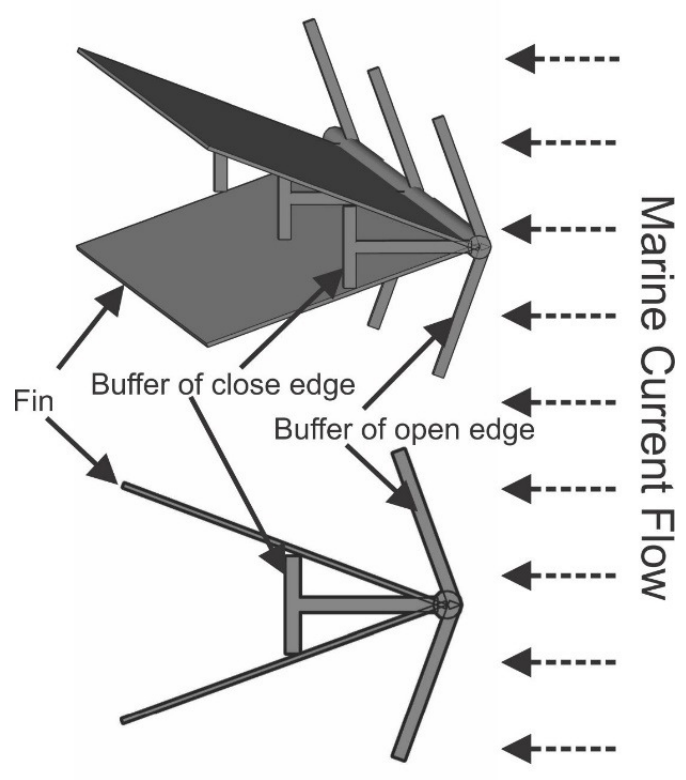

Fig 3. Closed fin Position
In figure 2 and figure 3 can be seen the structure of fin. The fins can open and close. This design will provide the potential the thrust is stronger because when the fin in the open state, it gives more capture, therefore, it produces more power to push the turbine. However, when it in the closed position, it provides more power loss. Part of the fin is 1) Buffer of open edge, aims to hold the fin sheets to form 70 degree position when the fin sheet opened. 2) Buffer of close edge, aims to keep the fins sheets not wholly closed so when the fin's sheet receives more power from behind it will be easy to reopen. 3) Fin sheets, it is useful for capturing ocean currents and converted into the boost to the turbine.

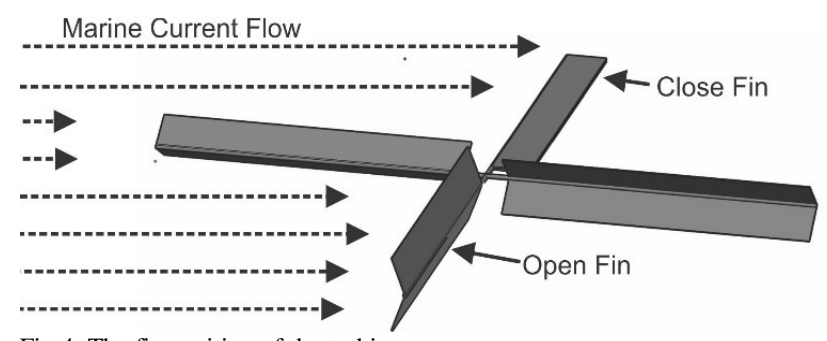

Fig 4. The fin position of the turbine

Figure4showstheformofaturbine, itconsistingoffou rpiecesofthefin.Italsoshowstheconditionofthedirecti onofoceancurrentsandthepositionsofthefinintheopen edandclosedstate.Thisdesigngivesonedirectionofrota tionoftheturbine, althoughtheoceancurrentswerecomi ngfromanydirection. Thethrustandnatureofthewater willopenandclosetheflippers.

\section{Generator}

The generator or the motor is the final component where the conversion of energy takes place into electricity. The generator used in permanent magnet types synchronous brushed motor [1].

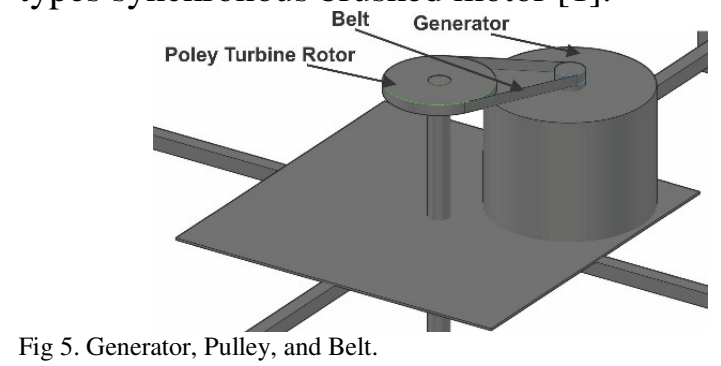

Figure 5 shows the position of the generator, pulley, and belt on the power plant. To generate 
electricity, it needs a generator which aims to convert the spin energy into electrical energy. These devices put in the centre of the power plant. To connect the generator to the turbine rotor requires 1) Pulley, the power plant use two pulley, that is pulley mounted in the turbine rotor, and pulley mounted on the generator rotor. Pulley on the turbine rotor is larger than the pulley on the generator rotor; the generator rotor becomes faster than the turbine rotor. 2) Belt, it used to connect two pulley, so when the pulley on the turbine spinning causes the rotor of the generator also rotates. 3) Dynamo, it used to convert the spin energy into electrical energy. We are using the LOW RPM generator.

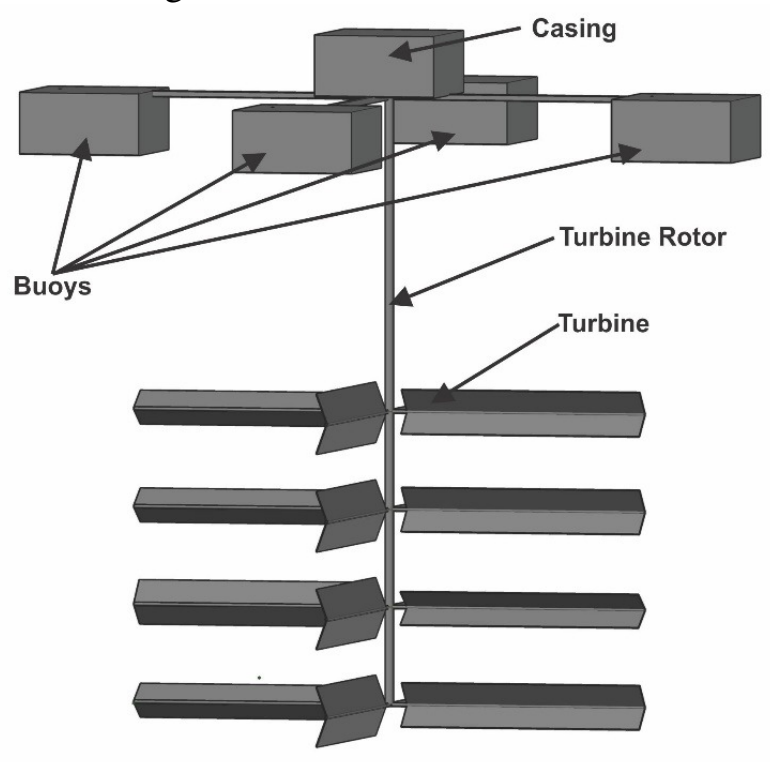

Fig 6. Complete figure of power plant

Figure 6 shows the intact form of the power plant. This power plant uses four turbines connected to a turbine rotor. The position of the turbine is entirely below the water level. The number of turbines will escalate the capture of marine current. To float power plant using four buoys. The buoys to make the generator, pulley, belt, and electric element are on the surface of the water and to keep turbines are still under the water surface. Generator casing aims to protect generator, pulley, belt and electrical part not directly exposed to sunlight and seawater.

\section{Expected Floatation}

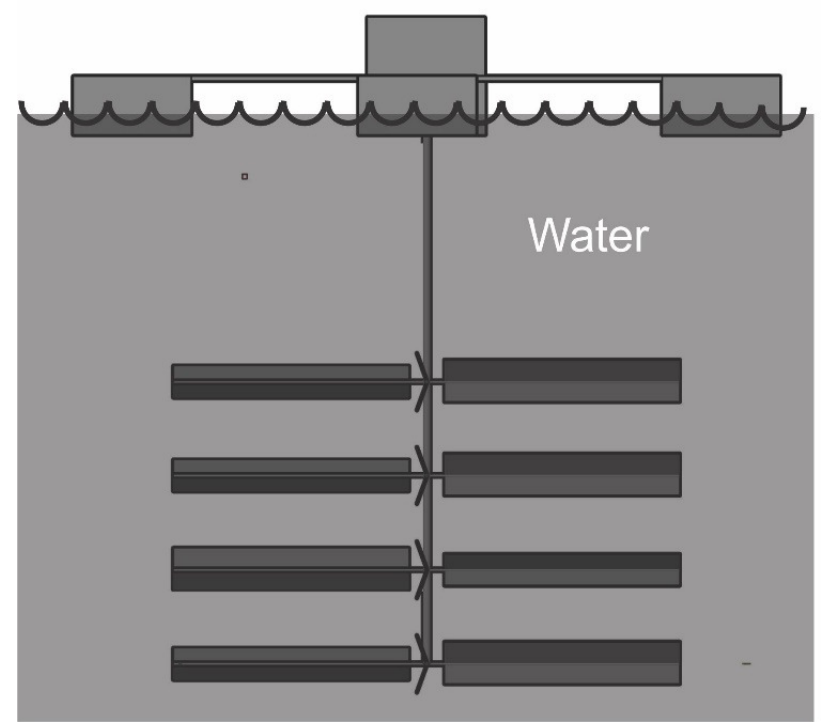

Fig 7. Floatation

Figure7showsthefloatingofthepowerplant.Powerp lantswillworkwelliftheturbineisbelowsealevel,andth egeneratorcasingisabovesealevel.

\section{CONCLUSIONS}

Indonesia is an archipelago country and suitable for applying Marine Current Micro-Hydro Power Plants. The power plant is still the design stage. Next, we will make a prototype to determine the performance of this power plant. For now, we cannot determine the generator capacity because it still has to experiment in real scale. I hoped this power plant could be a solution for people living on small islands that not accessed to electricity.

\section{REFERENCES}

1. Ambalia, A., Dolar, J., Koladiya, M. , Ansari, S., Ansari, Z. "Generation of Electricity from Ocean Waves", International Research Journal of Engineering and Technology (IRJET), Volume: 03 Issue: 04, pp. 1689-1692, Apr-2016.

2. Faiz1, J., Ebrahimi-salari, M. "Wave Power Resource in Iran for Electrical Power Generation", Word Renewable Energy, pp. 3412-3419, 2011.

3. K. Rhinefrank, et. al., "Novel ocean energy permanent magnet linear generator buoy", Journal of Renewable Energy, vol. 31.pp. 1279-1298, 2006.

4. Rahman, Mahbubur Md. et. al., "Power Generation from Sea Wave: An Approach to Create Renewable Energy", 
International Journal of Engineering and Techniques - Volume 4 Issue 2, Mar - Apr 2018

Global Journal of Researches in Engineering General

Engineering, Volume 13 Issue 1 Version 1.0, pp. 13-17.

2013.

5. Rangan, P.R., Karnyoto., A.S., Ambabunga, Y.A.M,

\&Rambulangi, A.C., "Design of River Flow Floating

Portable Micro-Hydro". International Journal of

Engineering and Techniques (IJET), Volume 4 - Issue 1.pp

593-597, 2018. 